\title{
Om »Omkring Grundtvigs Vidskab«
}

Indledningen ved forsvaret den 4. september 1998 og replikker til de to officielle opponenter

\section{Af Bent Christensen}

I »Grundtvig-Studier« 1999 tryktes Anders Pontoppidan Thyssens og Theodor Jørgensens officielle oppositioner ved forsvaret den 4. september 1998 af min disputats »Omkring Grundtvigs Vidskab. En undersøgelse af N.F.S. Grundtvigs forhold til den erkendelsesmæssige side af det kristeligt nødvendige livsengagement $(\mathrm{GV})$. Af flere forskellige grunde er det imidlertid først her til 2001-nummeret, jeg har fået skrevet et svar-som følger efter teksten fra manuskriptet til min indledning ved forsvarshandlingen. ${ }^{1}$

\section{Indledning ved forsvaret den 4. september 1998}

Jeg vil begynde med en slags mindeord. Som har en spøgefuld form, men skal forstås tilsvarende alvorligt!

Jeg er meget ked af, at vi ikke har Kaj Thaning blandt os mere. For hvor ville jeg gerne have hørt ham som opponent ex auditorio sige: " Jamen Bent Christensen har stadig ikke forstået radikaliteten i det, der skete med Grundtvig i vinteren 1831/32! «.

Hermed har jeg bekendt mit discipelforhold til Kaj Thaning. Og jeg vil yderligere udtrykke min taknemmelighed mod denne enestående Grundtvig-forsker ved at lade denne indledning tage udgangspunkt i, hvordan jeg i min bog faktisk har udtrykt min stærke anerkendelse af netop radikaliteten i Kaj Thanings Grundtvig-forståelse.

Men inden da vil jeg uden navns nævnelse udtrykke min taknemmelighed mod alle de andre Grundtvig-forskere, jeg har bygget på, både de døde og de levende, både de ældre og de yngre. Flere af dem er til stede her i dag.

Og jeg vil udtrykke min taknemmelighed for alt, hvad Københavns Universitet har gjort og betydet for mig, ikke bare her i disputats-forløbet, heller ikke bare under licentiatstudiet, men også helt tilbage fra dengang, jeg for temmelig nøjagtigt 34 år siden i netop denne bygning påbegyndte mit cand. mag.-studium i dansk og russisk! 
Men hvad nu min anerkendelse af radikaliteten i Kaj Thanings Grundtvig-forståelse angår, så kommer den jo fx meget klart til udtryk i min vurdering af forholdet mellem Kaj Thaning og den svenske Grundtvig-forsker Harry Aronson, idet jeg på s. 19 i bogen gør dette forhold op på den måde, at jeg siger, at det netop er i forbindelse med Kaj Thanings arbejde, Harry Aronsons disputats bør nævnes, idet Aronson nemlig for det første slet ikke beskæftiger sig med »den side af Grundtvig, som har med den videnskabelige erkendelse at gøre«. Og idet hans synsvinkel for det andet er

så traditionelt og kirkeligt teologisk, at han heller ikke får de mere overordnede overordnede sammenhænge omkring erkendelsesspørgsmålet ind i billedet. [...] Thaning [har] ret, når han påpeger, at Aronson slet ikke har forstået, hvor radikal Grundtvig er i sin anerkendelse af det foreliggende menneskelivs "saglige egenværdi«, også før og uanset kristendommen. Thaning ser-med sit ene øjelangt mere end Aronson, som altså noesten ingenting ser af det, der virkelig er interessant [fremh. her i GS] (GV 18f).

Men jeg kan også sige det på den måde, at det helt tilbage i begyndelsen netop var hos "Thaning og hans Grundtvig", jeg fandt et syn på det naturlige menneskelivs værdi og betydning, som jeg ikke, blot tilnærmelsesvis, havde set hos andre end de to.

Den afhandling, jeg skal forsvare her i dag, bygger på licentiatafhandlingen »Fra drøm til program «, som blev antaget i 1985 og udgivet i $1987^{2}$. Og jeg vil citere det allerførste afsnit i denne bog:

Den overordnede eksistentielle baggrund for nærværende arbejde er ønsket om en afklaring overhovedet af spørgsmålet om værdien og betydningen af menneskelivet her i verden mellem skabelse/ syndefald og genløsning. Spørgsmålet er dels, i hvilken grad og på hvilken måde livet her og nu i kristendommens lys kommer til at fremtræde med en »saglig egenværdi«, dels, hvilken betydning engagementet i livet her og nu har for gudsforholdet og gudsrigesforventningen (DP 9).

Her er hele mit anliggende præsenteret. Også den side af det, vi skal tale om i dag. Og når jeg siger »saglig egenvaerdi« om »livet her og nu«, så 
mener jeg jo det samme, som Kaj Thaning mener. Og for den sags skyld også Løgstrup!

Men når jeg videre taler om denne, sig selv godtgørende, "værdis" betydning for "gudsforholdet og gudsrigesforventningen «, så er jeg allerede kommet noget ind på mit eget område. For én ting er, at det er godt, vi i kristendommens lys kan se det, jeg kalder den foreliggende tilværelses »saglige egenværdi«. Men det er ikke nok. Det næste spørgsmål bliver jo: Hvad betyder dette syn inde i det kristne menneskeliv, jeg som kristen lever?

I denne forbindelse vil jeg tillade mig at nævne titlen på mit allerførste lille bidrag til Grundtvig-diskussionen. Hvad der i øvrigt er en helt særlig sammenhæng $i$ her i dag. Idet der var tale om et indlæg $i$ en diskussion mellem Kaj Thaning og - Theodor Jørgensen, som er officiel opponent her i dag. Titlen på mit indlæg i FØNIX var: »Menneske først, kristen så - og hvad så? «".

Ja, det er dette »og hvad såı, der lige fra første færd har været hoved-spørgsmålet for mig. Og jeg vil gerne gentage, at det altså drejer sig om spørgsmålet, hvilken betydning engagementet $i$ livet her og nu har for gudsforholdet og gudsrigesforventningen.

Og jeg nævner lige, at selv om det er kortest og præcisest at anvende de traditionelle teologiske ord om disse forhold, så er både spørgsmålet og det eventuelle svar jo det samme, hvis man bruger andre ord, ja, har andre forestillinger!

I øvrigt er nøgleordet »betydning«. Men inden jeg går nærmere ind i det, vil jeg runde præsentationen af mit discipelforhold til Kaj Thaning af med en redegørelse for, hvad der så er forskellen på hans og min Grundtvig-forståelse.

Det vil jeg også gøre ved at citere fra bogen, hvor jeg i indledningen siger, at

Medens der altså er en - måske temmelig enestående - overensstemmelse mellem Kaj Thanings og nærværende forfatters forståelse af, hvad der var Grundtvigs store spørgsmål, er der tale om til dels direkte modsatte vurderinger af, hvilken karakter hans afklaring i forhold til dette spørgsmål fik. Ganske særligt viser dette sig med hensyn til spørgsmålet, hvornår det er selve denne afklaring, der kommer til udtryk hos Grundtvig, eller hvornår det er andre motiver, der gør sig gældende. Og det ikke blot i forhold til årstallet 1832, men også i forhold til en lang række andre situationer og udsagn gennem 
det meste af Grundtvigs lange liv og forfatterskab. Der kan her først og fremmest peges på, hvordan Thaning ikke kan (eller vil) se storheden i Grundtvigs 1824-drøm, ja, overensstemmelsen mellem denne drøm, og så den »sekundære « eller »tilpassede-til-det-mulige» realisering af den, der faktisk blev tale om i den lange periode fra 1835 til 1872. Og der kan peges på, hvordan Thaning vurderer 1825opdagelsen meget negativt og ikke ser, at det er den, der giver Grundtvig den egentlige befrielse fra den apologetiske værnepligtsbyrde (se $\mathrm{DP}^{4}$ 94).

Generationsforskellen spiller utvivlsomt en afgørende rolle i det dobbeltforhold, der her er tale om. Den Thaning'ske ensidighed afspejler den samfundsmæssige, kulturelle og kirkelige situation i 30'rnes, 40'rnes og 50'ernes Danmark (GV 17).

Der er altså kirkesynet til forskel! Og jeg vil hævde, at det kirkesyn, hvorigennem jeg læser Grundtvig, er et kirkesyn, der passer til den situation, vi befinder os i nu her op mod årtusindskiftet!

Men selv om jeg selvfølgelig lægger stor vægt på den kirkesynsmæssige og kirkepolitiske side af sagen, vil jeg kraftigt understrege, at dette er noget, der er kommet til. I vekselvirkningen mellem Grundtvigstudiet og min præstelige erfaring. Fra begyndelsen var det kun de spørgsmål, jeg her allerførst præsenterede, det gjaldt.

Men der er jo selvfølgelig en sammenhæng. Hvis du har et dårligt kirke- og gudstjenestesyn, har du nok også et dårligt syn på dit liv ude i hverdagen: Den, der vil have sin gudstjeneste til at ligne et kaffebord, vil også have sit kaffebord til at ligne en gudstjeneste!

Det, jeg prøver at gøre op med, er ikke det Thaning'ske begreb "pilgrimssyn«. Nej, det er, hvad jeg fx vil kalde den halvflov-halvfriske og halvflov- halvbenovede måde at forholde sig til livet og denne verdens ting på. Eller den måde at ville leve som kristen på, der gør kristenlivet til sådan en højere form for hobby - ved siden af og i stedet for det rigtige liv. Så man fx ikke går til jazz- eller rock-koncert, men tror, det er liv, når man anvender noget tam kirke-umba-umba-musik i gudstjenesten!

Som det fremgår af begge mine bøger, mener jeg, at Grundtvig af på den ene side omstændighederne og på den anden side sin ømme samvittighed blev tvunget til at anlægge sit "monstrøse" ${ }^{5}$ syn på Folkekirken som en offentlig religionsanstalt, hvori den lille Jesu Kristi frimenighed kunne være gæst, og at dette videre medførte, at han måtte 
lade sin folkelige solidaritet komme til udtryk i en ejendommelig »sekundær teologi« om det lille danske hjertefolks særlige forhold til kristendommen.

Men når man har konstateret dette, er det nemt at drage Grundtvigs rene landvindinger ud og bruge dem $\mathrm{i}$, hvad jeg vil kalde en $» n y$ grundtvigsk minimal-katolicitet«.

Men her må jeg standse. Den videre udvikling af dette hører hjemme ude i den kirke-debat, som allerede er i fuld gang.

Tilbage til det anliggende, som har stået i centrum for min beskæftigelse med Grundtvig lige fra begyndelsen, $\mathrm{g}$ som fortsat vil være det centrale i mit discipel-forhold til ham: „det dennesidige livsengagements kristelige nødvendighed" eller "det kristeligt nødvendige livsengagement «. Og her i dag: »den erkendelsesmoessige side af det kristeligt nødvendige livsengagement «.

Som jeg sagde før: Nøgleordet er betydning! Alt er egentlig sagt $i$ den berømte strofe fra »Christenhedens Syvstjerne« (CSS):

Er os tomme Ord og Lyde:

Eget Folk og Fadres Land,

Veed vi ei, hvad de betyde

Meer end Mængde, Muld og Strand,

Tant er og hvert Ord, vi tale,

Om Guds Riges Bjerg og Dale,

Om Guds Folk og Menighed.

(CSS 6,60, VU VI 347)

Her er det de meget vigtige Grundtvig-begreber folk og fædreland, der specielt er blevet nævnt. Men det, der er selve anliggendet i denne strofe, gælder jo overhovedet alt, hvad der er indhold i vor tilværelse, alt, hvad der har betydning i vort liv.

Lad mig slutte med en modificeret gengivelse af nogle steder fra den summariske sammenfatning i bogens sidste kapitel:

Det er det skabte - men - faldne menneskeliv, der bekræftes og sættes i sit sande lys af den særlige åbenbaring, og det er dette menneskeliv, der er frelsens genstand. Samtidig gælder det, så at sige den anden vej, at selve ordet Gud - og dermed hele den særlige åbenbaring, ja, selve frelsen - alt sammen bliver betydnings-tomt, hvis den Gud (åbenbaring og frelse), der er tale om, ikke forstås som 
netop dette menneskelivs og dets verdens Gud - som både Skaber og Frelser.

Det er heraf, begrebet »det kristeligt nødvendige livs-engagement» følger - eller »det dennesidige livsengagements kristelige nødvendighed «- eller altså »er-os-tomme-ord-og-lyde-princippet«. Og allerede af, hvad der indtil nu er sagt, følger, at der helt særligt er tale om en erkendelse af betydning. Hvilket yderligere understreges af hele $\gg$ Logoskristologien«, dvs. troen på Kristus som det Guds billede og den Guds Sandhed, ved hvem verden er skabt, og som al mening og betydning $i$ verden er et aftryk af. Hvilket bekræftedes og forstærkedes i inkarnationens store begivenhed. Der er også en stor sammenhæng mellem Grundtvigs billedsyn og inkarnations-teologien.

Selve engagementet $i$ det at leve sit menneskeliv er naturligvis det helt primære. Men det menneskelige liv kan under ingen omstændigheder leves ureflekteret, så der vil - i særdeleshed for den troende kristne - altid være et element af »erkendelse« i selv den mest umiddelbare »levelse" af livet. Og det ligger i alt, hvad der hidtil er sagt, at det helt afgørende i såvel skabelses- som frelses-forholdet må være erkendelsen af Gud, det at kende Gud. Dette kan imidlertid - bortset fra alt det, der ligger i den særlige åbenbaring og i selve frelsen (og som unægtelig er helt afgørende, men dog noget andet, og for så vidt »tomt «) - kun ske indirekte, nemlig gennem menneskets erkendelse af sig selv og sin verden.

Der er ikke kun tale om, at det liv, der leves, gøres til genstand for en erkendelse, som er en indirekte gudserkendelse. Der er også tale om en stadig vekselvirkning mellem livet og den tydende erkendelse af det, i den forstand, at erkendelses-resultatet, tydningen, vender tilbage til livet igen som oplysning, hvorved selve livets levelse kommer til at give en ny og højere grad af erkendelse. $O g$ så videre.

Sådan kan det hele gøres op. Dybest set er der altså tale om skabelsesteologi, Logos-kristologi og inkarnations-teologi. Samt herlighedsteologi-eller-eskatologi. Det er intet mindre end selve Guds herlighed, på græsk $D O X A$, der yderst ude, men også i flere grader af en alleredeher-og-nu-måde, ligger bag Grundtvigs særlige og stadige brug af ordet "forklaring" - og dermed også bag hans brug af ordet "oplysning"!

Allerede i den første Dannevirke-afhandling har Grundtvig med meget enkle ord sagt, hvad det går ud på i den erkendelsesmæssige side af det kristeligt nødvendige livsengagement. Det er mod slutningen af 
afhandlingen »Om det Philosophiske Aarhundrede», hvor han siger, at »Historiens Maal [...] umulig [kan] være andet end det Timeliges Forklaring « (DV I 129).

Og hermed er det jo sagt, at hele formålet med skabelsen er af erkendelsesmaessig karakter i den forstand, at det hele er åbenbaring - eller åbenbarelse. Mennesket og hele menneskets verden er skabt med det formål, at mennesket ved at komme til erkendelse af sig selv og sin verden skal komme til erkendelse af Gud.

Det er en så stor teologi, der ligger under det alt sammen. Så stor, at man netop ikke skal gå og udsige den hele tiden, men bare - under den og inden for den - gå helt sagligt løs på livet og virkeligheden! Uden at lade den ene hånd vide, hvad den anden gør. Og i hvert fald uden hele tiden at sige det!

\section{Replik til Anders Pontoppidan Thyssen}

Medens ovenstående gengivelse af manuskriptet til min indledning ved disputatsforsvaret giver et øjebliksbillede, er der i det følgende tale om replikker, som er skrevet i tidsrummet december-februar 2000/2001. Ved forkortelsen GS + tal, henvises der til sider i »Grundtvig-Studier « 1999. Ved blot »s. «+ tal eller ved forkortelsen GV + tal henvises der til sider i »Omkring Grundtvigs Vidskab«. Ved DP + tal henvises der til »Fra drøm til program«. I det par tilfælde, hvor GV ikke er citeret helt nøjagtigt i GS 1999, følges GV.

Det første sted i Anders Pontoppidan Thyssens opposition, jeg vil svare på her, er afsnittet nederst GS 96 og øverst GS 97, hvor Pontoppidan Thyssen til sidst i sit referat af disputatsens kapitel 3 "Dannevirke-tiden 1816-1819" siger, at »Mærkeligt nok må han dog slutte med at konstatere, at Grundtvig hverken i Danne-Virke eller i perioden fra og med 1832 »gør noget forsøg på, direkte og egentligt at foretage den forstands- og begrebsmæssige 'forklaring' af tilværelsen, der angiveligt spiller en så afgørende rolle i hans videnskabssyn« (s. 202)«. Ja, det er mærkeligt, men jo altså også i den Grundtvig'ske betydning »bemærkelsesværdigt«. Det er et vigtigt resultat af undersøgelsen, at der intet sted hos Grundtvig er noget eksempel på, at han så meget som forsøger noget sådant. Hvilket dog ikke nødvendigvis betyder, at Grundtvig egentlig forsømmer noget. Han ville nok selv henvise til, at man jo stadigvæk befandt sig i dunkelheden og kun var $p a ̊$ 
vej mod »forklaringen«. Hvorved så imidlertid den ejendommelige skabelsesteologiske eller "sekundær-teologiske» "erkendelseseskatologi« i hans tænkning ville blive understreget. Og det er stadigvæk påfaldende, at det eneste bidrag fra Grundtvig selv til den store forklaringsvidenskabelighed, der spiller en så altbestemmende rolle i Indledningen til »Nordens Mythologi«, er det grundlag eller det »skelet«, han giver med »Haandbog i Verdens-Historien«. Men derom mere senere.

I referatet af »Mands Minde«-foredragene i kapitel 7 siger Pontoppidan Thyssen, at $»$ De vidner også om, at Grundtvigs vidskab (nu?) indebærer »en helt ny form for 'historisk-poetisk' videnskabelighed «"' (GS 99). Jeg husker ikke at have bemærket det i parentesen stillede spørgsmål ved forsvarshandlingen, men kan her præcisere, at der $i k k e \mathrm{i}$ afsnittet nederst på s. 366 er tale om en »1838-ny« form for videnskabelighed hos Grundtvig, men om, at den form for netop »historiskpoetisk " videnskabelighed, Grundtvig overhovedet har gjort sig til talsmand for, jo er en helt ny og for ham ejendommelig form for videnskabelighed. Det nye, der er tale om i 1838, er ikke en ny form for videnskabelighed, men tværtimod (hvad Pontoppidan Thyssen også (delvis) citerer), at Grundtvig nu, ikke mindst i »Mands Minde«, »retter opmærksomheden mod selve det danske folkeliv som hverken mere eller mindre end netop Liv betragtet « (GV 365), hvilket imidlertid bringer disse foredrag ind på en meget vigtig plads i hele det »altomfattende »kultur-« eller »livslevelses«-program« (GV 367), som Grundtvigs "vidskab« er tænkt ind i, og hvor der er »tale om en slags menneskelivets egen indre selv-oplysning, hvor studiet eller tilegnelsen af det liv, der har været levet, indgår i en livs- og oplysnings-vekselvirkning med det liv, der leves nu" (GV 366).

Men det er desværre rigtigt, når Pontoppidan Thyssen påpeger, at jeg har overset (eller i hvert fald ikke har fået gjort udtrykkeligt opmærksom på) »den påfaldende omstændighed, at Grundtvig ikke [i det s. 365 citerede stykke fra det første »Mands Minde«-foredrag] henviser til 1832 som det store vendepunkt, men udtrykkeligt til sin opvågnen $\mathrm{i} »$ Nordens Aand « 1808 (s. 365)« (GS 99). Jeg er dog glad for, at Pontoppidan Thyssen har påpeget dette, for det bekræfter jo min vurdering af »1832« og udviklingen derefter!

Til gengæld gør jeg i forbindelse med behandlingen af den tilsvarende kirkehistoriske foredragsrække »Kirke-Speil» (1860-1863, udg. 1871 og 1876) udtrykkeligt opmærksom på det påfaldende forhold, at 
Grundtvig overhovedet ikke nævner »Nordens Mythologi«, da han i det syvogtredivte og næstsidste foredrag begejstret taler om, hvordan han i England lærte »først i Henseende til Frihed som til alt menneskeligt at lægge hele Vægten paa Virkeligheden « (US X 356) (GV 459). »Hvad det i stedet munder ud i, er det råd til den kristelige frimenighed, at den, nu hvor sognebåndet er løst, gør alt for at blive i Folkekirken, ja, kun i yderste nødsfald træder ud af den! «. Idet jeg dog også gør opmærksom på, at »forklarings-perspektivet og hele den bredere menneskelige sammenhæng var trods alt kort, men stærkt repræsenteret i det syttende foredrag! (her [GV] s. 454f)« (GV 460). - Se også GS 104f.

I referatet af kapitel 8 citerer Pontoppidan Thyssen korrekt nok, at jeg i min behandling af tidsskriftet "Danskeren» bl.a. vil vise hvordan Grundtvig »stadig holder sin »Sorø«-tanke frem (s. 390f)«. Men det er selvfølgelig en fejl, og ikke Pontoppidan Thyssens mening, når han hertil føjer »altså forklaringsvidenskabeligheden « (som jo netop ikke skulle drives på den folkelige højskole i Sorø, men på det fællesnordiske superuniversitet i Göteborg) (GS 100).

Det er i en senere artikel i »Danskeren $\aleph^{6}$, Grundtvig (i forbindelse med en påvisning af nødvendigheden af den levende samtale på Rigsdagen!) kommer over i forklarings-perspektivet. $\mathrm{Og}$ her fremhæver Pontoppidan Thyssen korrekt, at jeg »finder det bemærkelsesværdigt, at Grundtvig »endnu - og under disse tilspidsede omstændigheder - husker det helt store forklarings-perspektiv ..." og »ligefrem knytter det sammen med den aktuelle kamp « (s. 396)«. Men når Pontoppidan Thyssen derefter spørger, "om ikke denne kobling af »forklaringen« til den aktuelle kamp mod tyskerne medfører en indsnævring af perspektivet « (GS 100), må jeg svare, at det bemærkelsesværdige netop er, at Grundtvig trods alt endnu husker forklarings-perspektivet. Det, min undersøgelse har afsløret, er jo, at Grundtvigs udvikling efter $1832 \mathrm{ikke}$ svarer til den enorme vægtlæggen på forklarings-videnskabeligheden, idet der dog er tale om meget komplicerede forhold, altså forhold, der er langt mere komplicerede, end fx Kaj Thaning har kunnet eller villet se!

I det $\varnothing v$ rigt korrekte referat af min behandling af det i min sammenhæng helt afgørende vigtige sidste afsnit $\mathrm{i} »$ Den christelige Børnelærdom « gør Pontoppidan Thyssen opmærksom på, at det er »Grundtvigs »kirkelige anskuelse« (fra 1825)«, Grundtvig sigter til med titlen "Det evige Livs-Ord af Vorherres egen Mund til Menigheden ". Og han bemærker kritisk, at denne anskuelse »ikke interesserer BC (skønt den omtales udførligt af Grundtvig)«(GS 101). Men for det første er det 
altså ikke Grundtvigs »kirkelige anskuelse«, der er genstand for min undersøgelse, endsige grunden til min interesse for $» D e n$ christelige Børnelærdoms« sidste afsnit, som i min sammenhæng er interessant, uhyre interessant, derved, at "hvor Grundtvig før har begrundet den universalhistoriske forklaringsvidenskabelighed rent skabelsesteologisk - eller i hvert fald sekundær-teologisk - gør han det nu klart kirkeligt og kristologisk " (GV 424). Og for det andet interesserer jeg mig faktisk overordentlig meget for Grundtvigs 1825-opdagelse af den historiske kirke som en mageløs kendsgerning, både rent kirkeligt, og for så vidt angår den betydning, den fär med hensyn til hele erkendelsesproblematikken! Jeg er særdeles opmærksom på de »enormt frigørende konsekvenser af Grundtvigs 1825-opdagelse« og lægger »afgørende vægt på de konsekvenser, 1825-opdagelsen får for Grundtvigs holdning til hele erkendelses-problematikken « (GV 221).

I sin drøftelse vedrørende afhandlingens anloeg og resultater lægger Pontoppidan Thyssen ud med en påpegning af, at det ikke er mange linier, jeg har ofret på metodiske spørgsmål. Hvad han unægtelig har ret i - idet jeg dog vil svare både ham og andre, der har fremsat en tilsvarende kritik, at den på sin vis ganske umiddelbare tilgang til Grundtvig måske er nok så kongenial og frugtbar, som en mere »flot « metode, hentet fra en fortidig eller nutidig filosof eller litteraturvidenskabsmand, ville have været. Og jeg mener, at dette netop viser sig $\mathrm{i}$, hvad Pontoppidan Thyssen opfatter som »et metodisk problem «, fordi der som jeg selv udførligt gør rede for det i disputatsens indledning - efterhånden viste sig en så stor "genstridighed i materialet " (GV 11), »at det oprindelige anlæg måtte opgives « (GS 101). Ja, jeg vil hævde, at det er her, min tilsyneladende så direkte, løse, bløde metode (nogle vil sige mangel på samme!) viser sin frugtbarhed. Jeg har ikke på forhånd haft hverken så megen metode eller så megen tese, at jeg har været forhindret $\mathrm{i}$ at se de hidtil upåagtede, ja, hidtil negligerede, forhold hos Grundtvig, der er blevet afdækket og fortolket i min disputats!

Pontoppidan Thyssen gengiver udmærket mine begrundelser og konklusioner, for så vidt angår den meget brede beskæftigelse med Grundtvig, der endte med at blive tilfældet i min disputats, altså hvordan hans "vidskab" kun kan forstås "som en del eller side af hele hans samlede kultur-syn og kultur-politik«, og hvordan Grundtvig inden for de danske, nordiske og fælleskirkelige/fællesmenneskelige helheder skal ses som en »total-digter", der »udfoldede sig i alle sine mange enkeltaktiviteter«. Men i vel en blanding af anerkendelse og (allerede) spy- 
dighed siger Pontoppidan Thyssen, at "Alle disse ting har BC faktisk skrevet om i disputatsafhandlingen «, for han fortsætter med at sige, at "hvis man stadig savner begrundelse for ordet "vidskab" (som var afhandlingens hovedspørgsmål!), har BC endnu en trumf: andre store personligheder har udmærket sig inden for bestemte felter, "men Grundtvig er helt enestående, fordi han i sin egen kæmpemæssige person forener alt dette« [...] (s. 486f, jfr. s. 14f)« (GS 102). Dette opfatter Pontoppidan Thyssen - med tydeligt ubehag - som endnu en af de mange Grundtvig-lovprisninger i mine to bøger. Men jeg er jo - som det også fremhæves i Theodor Jørgensens opposition (se fx GS 113f) ingenlunde ukritisk over for Grundtvig, hvilket imidlertid ikke forhindrer mig i at fastholde, at den måde, hvorpå han ser »den erkendelsesmæssige side af det kristeligt nødvendige livsengagement « som del af en stor livs- og kultursammenhæng, faktisk er helt enestående.

Så må jeg snarere give Pontoppidan Thyssen ret, når han siger, at det ofte er "svært at se, hvad han (BC) egentlig mener om Grundtvigs forhold til »den videnskabelige erkendelse«" (GS 103). Idet jeg dog kan forsvare mig med, at det faktisk også er svært at se, hvad Grundtvig selv helt præcist mener derom! Og hvornår! Afdækningen af disse forhold er vel netop en af mit arbejdes fortjenester. Jeg kan her henvise til afsnittet "Motiver og hovedpunkter gennem faserne" (GV 487ff). Og jeg kan ikke give Pontoppidan Thyssen ret, når han efter at have refereret dette afsnit siger, at »Hele dette forløb tyder på, at BC's vidskabs-tese står på svage fødder « (GS 105). For vel er det, jeg har fundet, temmelig anderledes end, hvad jeg - ud fra Kaj Thaning - oprindelig havde forventet. Hvilket også gælder et så vigtigt og tidligt tekstkompleks som »DanneVirke«. Men det viser som sagt kun, hvor frugtbar min metode har været. Tesen i disputats-teknisk forstand er jo identisk med konklusionen, som på bagsiden af disputatsens omslag er formuleret således:

På den ene side påvises det, at en absolut topvidenskabelighed (af humanistisk-livstydende karakter) er det øverste lag i den altomfattende kultursammenhæng, Grundtvig drømte om og arbejdede for.

Men på den anden side gøres der udførligt rede for, hvordan både indre, helt centrale, saglige og positive faktorer, og ydre, til dels meget negative faktorer, bevirker, at Grundtvig fra 0.1835 mere og mere koncentrerer sig om det danske folkelivs bevarelse, opvækkelse, »levelse« og oplysning - med Grundtvig selv i centrum som den store kirkelige og folkelige »totaldigter«. 
Pontoppidan Thyssen kan slet ikke lide, at jeg bruger ordet "system". Men der er nu ikke tale om, at jeg "vil opfatte Grundtvigs anskuelser [fremh. her] som et sammenhængende »system «" (GS 105). De gange, jeg anvender dette ord (som jeg jo nok burde have erstattet med et andet, mindre misforståeligt), er det altid om den samlede "struktur", som strækker sig lige fra forældrenes (og søskendes og kammeraters) opdragelse af de helt små børn og helt op til »Göteborg « - og hele vejen ned igen. Og ordet er altid sat i anførselstegn. I forbindelse med behandlingen af Grundtvigs allersidste »Marielyst-tale« skriver jeg således også, at idet Grundtvig her afviser som en misforståelse, at han skulle have haft i sinde "rat stille en ny Oplysning og Dannelse som den folkelige imod den fornemme, akademiske«, giver han »en slags sidste fremstilling af, hvad der i nærværende fremstilling - med et højst upassende ord-gennemgående er blevet betegnet som Grundtvigs »system ", for så vidt angår forholdet mellem den folkelige livs-oplysning og den højere videnskabelighed« (GV 452).

Hvad Pontoppidan Thyssen derefter skriver om Grundtvig som "snarere letbevægelig" (GS 105), kan jeg godt tilslutte mig, i hvert fald for så vidt angår det forhold, at han gennem hele sit liv har grebet snart sagt enhver aktuel lejlighed eller situation, der bød sig som en mulighed for at fremme hans anliggende. Hvormed der dog så ikke uden videre er sagt noget om, at selve anliggendet er blevet tilsvarende ændret. Typiske eksempler på, hvordan jeg selv har været opmærksom på dette forhold er, at jeg allerede i forbindelse med Grundtvigs debut-skrift »Lidet om Sangene i Edda" skriver, at det "har en særlig interesse derved, at det viser, hvordan han fra første færd har benyttet ydre anledninger til at fremføre sine tanker« (GV 39), eller at jeg påpeger, hvordan både folkehøjskoleskrifterne og Göteborg-skriftet har en klar tilknytning til, hvad der rent politisk var oppe i tiden (GV 343).

Men Pontoppidan Thyssen tænker selvfølgelig navnlig på bevægelser på dybere niveau'er, og så må det jo i virkeligheden være udtryk for en anerkendelse af min metode, når han siger, at »Grundtvigs særlige tænke- og virkemåde [...] må advare mod kategoriske sammenfatninger «, ja, når han siger, at »Mange af BC's »faser « ville ikke være nødvendige, hvis Grundtvig havde bundet sig til et fast tankesystem «, og når han siger, at "//vidskaben « [...] - ifølge BC's materiale - synes at miste sin mening og betydning efter 1832! «(GS 106). Hvilket dog skal forstås som noget af en spydighed. Og forholdene er som sagt meget komplicerede. 
Til slut omtaler Pontoppidan Thyssen den inddragelse (også ud over, hvad man (herunder jeg selv) umiddelbart ville have forventet) af det kirkepolitiske felt, der er tale om i begge mine to bøger. Og her må Pontoppidan Thyssen jo bemærke, at min vurdering af Grundtvig er "påfaldende negativ« (jfr. her s. 6). Hvilket altså virkelig er tilfældet. Der er her tale om et - fra begyndelsen fuldstændig utilsigtet - resultat af min Grundtvig-forskning. Men undervejs er det blevet mere og mere klart, at der er en nøje sammenhæng mellem kirkesynet - både hos Grundtvig selv og hos Grundtvig-forskerne! - og så de forskellige ting, der har været særligt fokuseret på i mine to Grundtvig-undersøgelser.

Men nu til Pontoppidan Thyssens bemærkninger til min behandling af den kirkepolitiske side af sagen. Pontoppidan Thyssen kan tydeligvis ikke lide - eller forstå - at jeg forholder mig kritisk til Grundtvig, »fordi han i sin kirkepolitik ville sondre mellem kristne og ikke-kristne og dermed svigtede »folkekirken « som et fællesskab af alle dens medlemmer«. Og han finder det »mærkeligt«, at jeg ser Grundtvigs 1832-løsning som hængende sammen med, "at han led under følelse af isolering og havde et »desperat behov« for at finde en udvej af »klemmen« (Fra drøm - s. 94-144, især 142-144, 296f)«(GS 107). Pontoppidan Thyssen finder min fremstilling af kirkekampen »i høj grad ensidig«. »I den historiske sammenhæng er der ikke basis for hans [altså mine, BC's] psykologiske motiveringer, og Grundtvigs kirkepolitiske reaktioner var ikke urimelige« (GS 107).

Efter at have suppleret referatet af min fremstilling med sin egen skitsering af den historiske sammenhæng og i forbindelse dermed at have mere end antydet, at der ikke har været taget nok hensyn til denne i mine undersøgelser, ligesom jeg åbenbart heller ikke i denne forbindelse skulle have haft øje for den »sans for helhedssammenhænge«, som jeg ellers lægger så stor vægt på hos Grundtvig, siger Pontoppidan Thyssen, at man over for min fremstilling snarere føler sig "hensat til aktuel polemik til forsvar for »folkekirken««! (GS 108). Og det er yderst interessant, at Pontoppidan Thyssen, idet han ser min holdning som "nært beslægtet med Thanings«, om denne siger; »Men Thaning ville åbenbart nødig kritisere Grundtvig, så han talte i stedet om »en tydelig afsporing i den grundtvigske bevægelse«! (»Menneske først -« s. 502, jfr. »Fra drøm - « s. 296)«. Retfærdigvis skal det dog nævnes, at Pontoppidan Thyssen slutter med, for sit eget vedkommende at erkende, "at sagen i sig selv er noget kompliceret« (GS 108f). 
Nu kan jeg ikke gå i enkeltheder her, men jeg mener at have påvist, at det helt afgørende punkt, hvor knuden strammedes for Grundtvig, var forløbet fra april 1831, hvor han erklærede sig villig til at gå i spidsen for en frimenighedsdannelse, til 1. marts 1832, hvor kongen underskrev resolutionen om, at Grundtvig skulle have tilladelse til for sin person at holde dansk aftensang i Frederikskirken. $\mathrm{Og}$ inden for dette forløb igen var de helt afgørende punkter Grundtvigs samtale med kancellipræsident Stemann 11. februar 1832, hvor denne afviste muligheden af, at der skulle kunne gives tilladelse til en frimenighedsdannelse, og Grundtvigs samtale med biskop P.E. Müller 27. februar 1832, som mundede ud i den $\mathrm{Kgl}$. resolution med tilladelsen til aftensangsgudstjenesterne (DP $113 \mathrm{ff}$ ). På sin vis har både de danske myndigheder og Grundtvig jo efter god dansk skik - optrådt moderat og »rimeligt«. Det, jeg bebrejder Grundtvig, er egentlig »kun«, at han på den ene side for sin meget ømme samvittigheds skyld, mht. hvem han ville anse for virkelige kristne, og på den anden side af hensyn til sin egen stilling i samfundet og i forhold til hele folket, absolut skulle lave en så udtrykkelig, udførlig og »monstrøs « ${ }^{5}$ konstruktion, for så vidt angår sit syn på statskirken/ folkekirken som en organisation, han og de andre "gammeldagstroende" (»Jesu Kristi frimenighed«) kunne blive i. Som A.M. Allchin, citeret efter hukommelsen, sagde, da jeg under et af Grundtvig-Selskabets årsmøder havde forklaret disse forhold: »Oh, he had to call the church not a church in order that he could stay in it!«. - I øvrigt vil jeg henvise til min inddragelse af polemikken mellem Kaj Thaning og P.G. Lindhardt i forbindelse med min gennemgang $\mathrm{i} » O$ Omkring Grundtvigs Vidskab« af »Den christelige Børnelærdoms« sidste afsnit ${ }^{7}$.

Det helt afgørende i forbindelse med min disputats (men også allerede i forbindelse med $» F r a$ drøm til program «) er, at de kirkepolitiske omstændigheder kan ses som årsagen til det mærkelige forhold, at Grundtvig i Indledningen til »Nordens Mythologi« kommer så højt op i de store forklaringsvidenskabelige højder (og drager så ejendommelige kirkepolitiske konsekvenser deraf), når det så viser sig, at han gennem resten af sit liv stiger ned fra disse højder igen. Hvad han altså gør også uanset hvor dårligt det bekommer mine kritikere, at jeg bruger ordet "nedstigning" (som jeg i øvrigt har fra Aage Henriksen! ${ }^{8}$ ). Men det er som sagt meget kompliceret. For der er ingen tvivl om, at det helt klart fra »Danne-Virke« af og gennem resten af Grundtvigs liv er for i videste forstand - erkendelsens skyld, mennesket skal engagere sig i dette liv. Og der er heller ingen tvivl om, at den - igen i videste forstand 
- videnskabelige erkendelsesvirksomhed på også allerhøjeste niveau hele tiden hører med i den sammenhæng, Grundtvig ser for sig. Ja, vel at mærke ser for sig! For dette syn behøver jo ikke indebære, at Grundtvig personligt skulle praktisere - eller kæmpe lige ihærdigt for - alle dele af det lige her og nu. Hvad der kan være grund til at spørge om, er, i hvilken grad Grundtvigs skiftende vægtlæggen på netop den videnskabelige erkendelse, hænger sammen med de skiftende, ikke mindst kirkepolitiske omstændigheder. Og jeg er også overbevist om, at det er rigtigt, når jeg hævder, at det helt centrale og afgørende for Grundtvig - /)totaldigteren Grundtvig " - er selve livets, hvilket for ham vil sige det danske folkelivs, lykkelige og oplyste »levelse«. Hvor den videnskabelige erkendelsesvirksomhed er en vigtig, men speciel og »tjenende« del af denne »levelse«.

\section{Replik til Theodor Jørgensen}

De indvendinger, Theodor Jørgensen har mod mit arbejde, fordeler sig på fire hovedtemaer: 1. At jeg har min egen kulturteologiske drøm eller vision, som Grundtvig tjener som hjemmelsmand for, og som jeg i en tilbagerettet brug anvender som målestok på Grundtvig, hvilket fører til en skævvridning af min undersøgelse. -2 . At jeg burde have arbejdet mere problemorienteret-systematisk med Grundtvigs tænkning. - 3. At jeg i forbindelse dermed i højere grad burde have læst Grundtvig idehistorisk-kontekstuelt. - 4. Endelig benytter Theodor Jørgensen mit "ellipse-billede« af motiverne bag Indledningen til "Nordens Mythologi« (med henholdsvis universalvidenskabeligheden og den kirkelige problematik som de to centrer) til at præsentere et andet ellipse-billede, hvor de to centrer eller poler udgøres af henholdsvis det universelle og det partikulære.

$\mathrm{Nu}$ er det jo i nærværende sammenhæng ikke Bent Christensen og hans eventuelle drømme, visioner og programmer, men Grundtvig, det skal handle om. Men jeg kan selvfølgelig ikke benægte, at jeg faktisk har nogle visioner og et program. Det spørgsmål, der kan blive tale om i forbindelse med min disputats, er dog udelukkende, om dette forhold, ja, i det hele taget mit erklærede »brugs-motiv«, har haft en dårlig, skævvridende indflydelse på mit Grundtvig-studium. Hvad jeg altså ikke mener det har, men at det tværtimod har indebåret nye, frugtbare vinkler og belysninger! Og jeg vil nu prøve at sige lidt om, hvordan »mit liv 
med Grundtvig " $"$ har udviklet sig siden faktisk begyndelsen af 1970'erne - med særligt henblik på, i hvilken grad og på hvilken måde min egen side af det kan have haft indflydelse på min disputats.

Som det fremgår af ovenstående Indledning, var det selve synet på livet her og nu, der først hos Thaning og derefter hos Grundtvig selv vakte min opmærksomhed. Og det er jo fortsat her, det absolutte hovedspørgsmål ligger. På grundlag af det Grundtvig-studium, der førte frem til »Fra drøm til program «, har jeg dannet betegnelserne »det dennesidige livsengagements kristelige nødvendighed « og »det kristeligt nødvendige livsengagement $« . O g$ der er så vidt mig bekendt ingen, der har anfægtet mine resultater på dette absolutte hoved-område. Da jeg fik idéen til disputatsen, var det (som det også fremgår af dens undertitel) nu den særlige erkendelsesmoessige side af det kristeligt nødvendige livsengagement, jeg ville undersøge. Og jeg kan også røbe, at jeg vist omtrent samtidig faktisk begyndte at tale om en tredje del i en trilogi! (Se note 9). Eller som jeg yndede at sige: et tredje trin i raketten! Desværre bliver det nu næppe muligt for mig at få en bog ud af det, men en artikel her i Grundtvig-Studier håber jeg det kan blive til. Så må en anden skrive bogen ${ }^{10}$. Jeg havde også straks en arbejdstitel: „En undersøgelse af den poetiske side af N.F.S. Grundtvigs forhold til det kristeligt nødvendige livsengagement «. Fra sommeren 2000 har den fulde (projekt-) titel været: „Totaldigteren Grundtvig. En bestemmelse af Grundtvigs egenart som digter og en vurdering af forholdet mellem det poetiske potentiale i hans tænkning og graden, i hvilken det er udfoldet $\ll$.

Hvad mit eget program angår, dvs. hvad angår det, jeg i forlængelse af selve min Grundtvig-forskning, vil bruge den indsigt, viden og inspiration til, den har givet mig, kan jeg henvise til den artikelrække, jeg i forlængelse af disputatsen har haft i Dansk Kirketidende. Der er tale om først artiklen: »Fra »Fra drøm til program« til Program«, som kom allerede i 1995. Dernæst artiklen »Livsvidenskabelig efterskrift« (nemlig til disputatsen), som kom i 1998. Og endelig den to år efter disputatsens udgivelse trykte artikel $» L i v s p o e t i s k$ Indledning «. De, der måtte ønske at stifte nærmere bekendtskab med mit eget program, kan læse disse artikler ${ }^{11}$. Det eneste, jeg yderligere vil sige her, er, at vel taler jeg i disse artikler udtrykkeligt om det ønskelige i - på en eller anden måde! - at realisere (i hvert fald noget af det, der lå i) Grundtvigs Göteborg-tanke, og vel taler jeg også om en genoplivelse af Folkehøjskolen (også som en »dimension« i undervisning uden for selve denne 
institution). Men jeg gør det udtrykkeligt ud fra Grundtvigs eget princip om, at det skal være (let omskrevet) på en med tidens tarv og vilkår passende måde, ja, mit eget hovedprincip er princippet om, at de Grundtvigtanker, der i hans udformning uhjælpeligt hører fortiden til, må hœeves op $i$ højere noevnere, ligesom jeg gør meget ud af at vise, hvordan Grundtvigs tanker om videnskabeligt og kulturelt samarbejde mellem kristne og ikke-kristne meget fint vil kunne bruges i vor egen jo ikke bare moderne, men post-moderne situation. For slet ikke at tale om hvor godt mit kirkesyn passer til den post-moderne situation. Jeg går jo fx ind for Folkekirkens adskillelse fra staten over en periode på 30 år! Kort sagt: Det passer simpelt hen ikke, at mit program (hvis jeg endelig ville gøre det til målestok for Grundtvig i min rent forskningsmæssige beskæftigelse med ham) skulle forlange af Grundtvig, at han skulle blive ved at kæmpe for den kristne enhedskultur. Hvis jeg endelig bebrejder ham noget, er det jo, at han prøver - ved hjælp af forskellige konstruktioner og besværgelser - alligevel at få bevaret noget af en enhedskultur, og i hvert fald at få sikret sin egen position i det danske samfund!

I det følgende skal det nu, så vidt muligt, udelukkende dreje sig om min forskningsmæssige beskæftigelse med Grundtvig, og jo især som den foreligger i »Omkring Grundtvigs Vidskab«. Og her er der kun to punkter, hvor man kan sige, at mit eget program er inde i billedet. Det ene er, at jeg nogle steder i disputatsen giver udtryk for, at det kunne være ønskeligt at realisere Grundtvigs Göteborg-tanke. Det gælder det sted, Theodor Jørgensen citerer GS 114f. Her udtrykker jeg forståelse for, at Grundtvig efter omstændighederne opgav at arbejde videre med Göteborg-tanken, for i stedet at koncentrere sig om udviklingen af et folkeligt oplysnings-program. Men jeg føjer til, at

når dette er sagt, må man desto mere holde sig for øje, at potentialet i det, Grundtvig har ydet, under andre og mere gunstige omstændigheder vil kunne [og her er det, Theodor Jørgensen indsætter sit: »(bemærk futurums-formen) «] få en helt anderledes storslået udfoldelse, også på allerhøjeste akademiske og kulturelle niveau! (GV 526).

Og jeg må da også indrømme, at selve fremstillingen i »Omkring Grundtvigs Vidskab« slutter med, at jeg endnu en gang slår fast, "at hvor utroligt det end lyder, så er Grundtvigs store universalhistoriske vidskabs- og oplysnings-program kun i yderst ringe omfang blevet ført 
ud i livet «, og føjer til, at man altså »simpelt hen bare ikke [kan] forstå, hvad Grundtvigs vidskab er (eller var tænkt som), hvis man ikke gør sig klart, i hvor ringe omfang den indtil nu er blevet realiseret! «. Hvorefter fremstillingens allersidste sætning kommer til at lyde: »Hvilken forståelse så til gengæld er den første forudsætning for, at en sådan virkeliggørelse eventuelt kan komme til at finde sted! «(GV 513).

Det kan selvfølgelig altid diskuteres, om det er rigtigt, at sige sådan i en disputats - oven i købet lige til allersidst. Men det er i hvert fald en kendsgerning, at Grundtvigs Göteborg-tanke endnu ikke er blevet realiseret. Og det må vel også kunne gå an at lade en så stor undersøgelse af et dybt teologisk funderet erkendelsesprogram munde ud i et ønske om, at den måske kunne være en del af grundlaget for en fremtidig realisering af det. Det afgørende spørgsmål er, om dette ønske har haft en uheldig indvirkning på den forskningsmæssige kvalitet af mit arbejde. $O g$ det skal jeg vende tilbage til, når jeg svarer på de enkelte dele af Theodor Jørgensens kritik.

For der er jo også et andet punkt, hvor man vil kunne sige, at mit eget syn kan have medført en skævvridning af undersøgelsen. Og det er kirkesynet (eller det kirkepolitiske syn), hvor det jo er klart, at jeg står $i$ et meget kritisk forhold til såvel Grundtvig selv og grundtvigianismen som overhovedet til den opfattelse, at den nuværende stats-folkekirke blot skulle være »en ramme om evangeliets forkyndelse«. Derfor vil jeg nu give en kort samlet oversigt over udviklingen i min Grundtvigforskning, for så vidt angår netop kirkesynet.

Som det allerede er fremgået, gik jeg i begyndelsen af 1970'erne til Grundtvig - gennem Kaj Thaning - med det ene store formål at fordybe mig i, populært sagt, „Grundtvigs livsbekræftende teologi«. Og om mit kirkesyn på det tidspunkt kan jeg sige, at jeg sådan set ikke havde noget! Jeg var så stats-folkekirkelig som nogen. Men jeg kan også godt oplyse, at min præstelige og almindelige (herunder mellemkirkelige) erfaring, først på Bornholm og gennem de sidste mange år på Lolland, sammen med min orientering og deltagelse $\mathrm{i}$ den almindelige kirkelige debat, selvfølgelig har bidraget væsentligt til, at jeg i dag virkelig må siges at have et kirkesyn! Idet denne udvikling vel at mærke er sket $i$ kraftig vekselvirkning med de ting, jeg - uden at det fra begyndelsen på nogen måde havde været tilsigtet - fik afdækket i mit Grundtvig-studium.

For hvad nu selve Grundtvig-studiet angår, så lagde jeg altså ud som helt ukritisk begejstret Thaning-discipel. Da jeg begyndte at lægge grunden til min licentiat-afhandling, var det faktisk min hensigt, at mit 
bidrag til Grundtvig-forskningen mere eller mindre skulle bestå i en systematisk fremstilling af de ting, Thaning havde vist mig hos Grundtvig. Det var Leif Grane, som var min vejleder lige til at begynde med (hvorefter det blev Jørgen I. Jensen, og disse to blev mine bedømmere), der anbefalede mig at gå historisk til værks, bl.a. derved, at jeg ikke bare begyndte i 1832 , men gik tilbage til 1825 . Det gjorde jeg så, hvilket snart førte mig et år længere tilbage, nemlig til $1824 \mathrm{og}$ »NyaarsMorgen «, hvis storhed hurtigt gik op for mig, så at det kom til at indtage en hoved-plads i »Fra drøm til program «.

Det første, der fik mig til at forholde mig kritisk til Kaj Thaning, blev netop vurderingen af »Nyaars-Morgen«. For selv om dette store digt og den programmatiske Indledning til »Nordens Mythologi« ikke uden videre er sammenlignelige, måtte jeg dog stille det spørgsmål, om der ikke allerede her i 1824 var tale om et særdeles positivt forhold til denne tilværelse, og om Grundtvig ikke herfra, under andre og mere gunstige omstændigheder, ville have kunnet udvikle sig på en måde, der svarede til, hvad der blev tilfældet efter 1832. Men omstændighederne i 1820 'rne var alt andet end gunstige. »Nyaars-Morgen « blev ikke ænset. Og så kom Kirkekampen - som 1825-opdagelsen og »Kirkens Gienmæle«, på grund af professor Clausens og i det hele taget samfundets reaktion, kun gjorde værre for Grundtvig. For i sig selv var 1825opdagelsen jo klart af stærkt befriende karakter. Alt dette kom jeg til at fordybe mig mere og mere i. For det var jo baggrunden for »1832«. Og på denne baggrund kom jeg så også til at se, i hvor høj grad Grundtvigs arbejde med Indledningen i vinteren 1831/32 også var motiveret af hans behov for at få sig vredet ud af den helt umulige kirkelige klemme, han var kommet i. Ja, arbejdet med Indledningen måtte ses i sammenhæng med den kompromis-løsning på Grundtvigs - og Danmarks - problem, Frederikskirke-aftensangsordningen blev. (Se ovenfor s. 193f)

Uden at det som sagt på nogen måde havde været inde i billedet fra begyndelsen, kom disse ting således til at indtage en væsentlig plads i »Fra drøm til program«. Og det er slående, at den titel, der blev opgivet til min licentiat-forelæsning i november 1985, lød: "Var Grundtvigs nyerkendelse i 1832 en tragisk hændelse? «. (Manuskript-teksten blev bragt i Grundtvig Studier 1989-1990).

Den kritiske holdning, der nu var tale om, var altså på ingen måde en holdning, jeg havde haft på forhånd, og så lagt ind i min forskning. Det omvendte var tilfældet. Det var virkelig »forsknings-oplevelse« at 
afdække disse sammenhænge, som ingen havde set (eller villet se) før, i hvert fald ikke så tydeligt og på den måde.

I løbet af arbejdet med »Omkring Grundtvigs Vidskab«blev de ting, jeg havde opdaget i min første undersøgelse, yderligere bekræftet - med frugtbare virkninger for ikke mindst min bestemmelse af hele Grundtvigs »sekundære teologi«, og jo ganske særligt sekundærteologien om Danmarks og det danske folks helt særlige plads i Guds husholdning.

Jeg mener altså ikke, mit kirkesyn har haft andet end netop frugtbar betydning for mit arbejde med Grundtvig. Idet der altså i høj grad ligefrem har været tale om en vekselvirkning! Og hermed vil jeg gå over til at svare på de enkelte dele af Theodor Jørgensens opposition.

Nederst på side GS 111 siger Theodor Jørgensen, at jeg - med Grundtvig som inspirator og hjemmelsmand - har min egen kulturteologiske drøm eller vision, men at mit problem er, at $\gg$ det kunne Grundtvig efter [min] mening have gjort bedre eller mere konsekvent «. Men dertil må jeg sige, at det jo altså ikke er mit program, jeg måler Grundtvig på - så meget desto mindre, som det program, jeg sådan set har, jo i høj grad er blevet til på grundlag af Grundtvig-studium.

Skal man endelig tale om, at jeg er blevet »skuffet « over Grundtvig (som Theodor Jørgensen siger GS 113), så er det, som jeg udførligt har gjort rede for det i disputatsens indledning, fordi det viste sig, at det forholdt sig temmelig anderledes med hans »vidskab«, end man skulle tro, når man trods alt stadig med Kaj Thaning så Indledningen til »Nordens Mythologi« som den store gennembrudstekst. For jeg vil fastholde, at når den universalhistoriske forklaringsvidenskabelighed i 1832 spillede en så afgørende rolle for Grundtvig, at han af hensyn til den udviklede en helt uhyrlig kirkepolitisk konstruktion, så er det altså påfaldende, at han aldrig siden begiver sig op i de højder, der er tale om i 1832-Indledningen. For det $\mathrm{g} \varnothing \mathrm{r}$ han ikke. $\mathrm{Og}$ det er i denne forbindelse, min brug af ordet »nedstigning « kommer ind. Og selv om jeg altså i helt direkte forstand bruger det snævert om det forhold, at Grundtvig ikke siden "kommer så højt op" som i Indledningen til »Nordens Mythologi«, gælder det jo også hele det forhold, Aage Henriksen betegner som "nedstigningen, Grundtvigs forvandling til grundtvigianisme" (se note 8). Men der er jo mange faktorer i dette; der er tale om et kompliceret samspil mellem ydre og indre ting, mellem hvad Grundtvig selv ville og hvad der var muligt, osv.

På side GS 112 siger Theodor Jørgensen, at jeg »opfatter Grundtvig som repræsentant for og forsvarer af en kristen enhedskultur, som også 
hans videnskabsforståelse er udtryk for «. Men igen er forholdet jo mere kompliceret end som så, idet man fx må skelne mellem »DannevirkeGrundtvig « 1816-19 og »efter-1832-Grundtvig «, som ikke taler om »den ved troen oplyste fornuft " $^{12}$, men om den kristelige anskuelse, som netop ikke er det samme som selve den kristne tro. Og selv om Grundtvig altså i Indledningen til »Nordens Mythologi« bruger hensynet til det videnskabelige og kulturelle samarbejde mellem kristne og $/$ naturalister" som begrundelse for sin kirkepolitiske konstruktion - hvorved mest muligt af, om ikke kristen, så dog kristelig, enhed skulle kunne bevares - så er hans videnskabsforståelse som sådan ikke bundet til en enhedskultur. Det kommer frem i det meget vigtige slutafsnit af $»$ Den christelige Børnelærdom«, hvor Grundtvig (men igen i en meget kompliceret motiv-sammenhæng!) giver en storslået teologisk begrundelse for den videnskabelige erkendelses nødvendighed i selv den mindste lille frimenighed! (GV 418ff - US IX 579f).

På side GS 113 citerer Theodor Jørgensen det sted på side GV 485, hvori jeg stiller det spørgsmål, hvor meget Grundtvig i virkeligheden interesserede sig for den videnskabelige erkendelse, idet store dele af hans beskæftigelse med erkendelsesspørgsmål i virkeligheden gælder andre ting, og idet han jo efterhånden mere og mere koncentrerede sig om henholdsvis den lille kristne menigheds og det danske folks liv. Og det er $\mathrm{i}$ forbindelse hermed, Theodor Jørgensen taler om min "skuffelse«. Men det forhold, at det i løbet af min undersøgelse viste sig, at der var mindre »vidskab « hos Grundtvig, end jeg havde forventet, det er jo ikke det samme som, at jeg uden videre vil kritisere Grundtvig for, at han - og da især efter omstændighederne - koncentrerede sig om livet. Og jeg gentager: Det, der er påfaldende, er, at Grundtvig i Indledningen til »Nordens Mythologi« kommer op i så store højder (hvad han jo virkelig gør!), men at han så straks bevæger sig nedad igen - mod folkelivet, dets redning og bevarelse, dets oplysning, hvilket jo som sagt ikke behøver være noget dårligt! Virkeligheden og livet er vigtigere end videnskaben, kommer bogstavelig talt foran den.

Lidt senere siger Theodor Jørgensen så, at Indledningen til »Nordens Mythologi«

er det skrift, hvor Grundtvig ifølge præses også går på kompromis med sine egne visioner om universalvidenskaben i den omfattende eskatologiske forklarings tjeneste ved at opgive at stå fast på en primær-teologisk eller åbenbaringsteologisk begrundelse af den til 
fordel for et samarbejde med »naturalisterne af ånd «. Det sker ifølge præses, fordi Grundtvig ønsker at komme ud af den kirkelige og kulturelle isolation, han indtil da havde befundet sig i (GS 113).

Men når jeg taler om et kompromis i 1832, så er det jo det kirkepolitiske kompromis! Grundtvigs skelnen mellem egentlig kristen tro, og så den anskuelse, som de egentlig kristne og »naturalisterne « kunne være fælles om, ligger på et andet plan. Selv om der jo - for Grundtvig - var en vis sammenhæng. For det var jo netop fællesskabet om anskuelsen, og dermed om kulturen og videnskabeligheden, der var grundlaget for fællesskabet om stats-, senere folkekirken som en fælles borgerlig indretning eller offentlig religionsanstalt.

Ja, tingene er komplicerede. Én ting er forholdet mellem, hvad Grundtvig selv må sige, som troende kristen, og så, hvad han - på anskuelsesplanet - kan være fælles med »naturalisterne« om. En anden ting er, at når Grundtvig kan tale så stort om et fællesskab mellem kristne og ikke-kristne, så bygger det netop på den skabelsesteologi, han som troende kristen har (bl.a. som arv fra Irenæus). For vel er det rigtigt, at $\mathrm{i}$ det helt store kristne, frelseshistoriske perspektiv, dér er »forklaringen « det samme som »herliggørelsen« i Guds Rige. Men Grundtvig opererer jo også med en i selve skabelsen indbygget forklarings-udvikling eller vækst, hvorigennem den menneskeslægt, der ved skabelsen var som et nyfødt barn - trods syndefaldet og dets virkninger - ved tidens ende skal nå sin fulde udfoldelse. Man kan også sige, at den »forklaring", Grundtvig taler om i Indledningen til »Nordens Mythologi«, er en »sekundærteologisk «, men jo egentlig skabelsesteologisk, parallel til selve genløsnings-herliggørelsen. (Derfor forstår jeg heller ikke, hvad Theodor Jørgensen mener, når han på side GS 118 siger (hvis det er det, han gør), at i »Christenhedens Syvstjerne«bliver verdenshistorie frelseshistorie).

Videre spørger Theodor Jørgensen, om jeg ikke overbetoner de rent psykologiske forhold i forbindelse med Grundtvigs måde at reagere og forholde sig på - »og dermed apologetikken, polemikken, strategiske hensyn m.m. i Grundtvigs skrifter" (GS 114). Men det mener jeg ikke jeg gør. Skønt, hvad vil det sige at over-betone? Det er i hvert fald helt givet, at der hos Grundtvig var tale om på den ene side en ejendommelig ømskindethed med hensyn til, hvad han kunne tåle hos dem, han skulle regne for sine virkelige medkristne, og på den anden side et stærkt ønske om at være centralt placeret $i$ et vekselvirkningsforhold med hele det 
danske folk. Og jeg mener godt, man kan tillade sig at gøre det tankeeksperiment, at hvis Grundtvig havde været skruet lidt anderledes sammen rent psykologisk, og altså navnlig mht. denne kirkelige »ømskindethed «, så kunne han med den samme storslåede teologi have talt om kirken og om forholdet mellem kristne og ikke-kristne på en anden måde - med grænserne liggende nogle andre steder.

Men når Theodor Jørgensen derefter spørger, om »den påpegede selvmodsigelse « (GS 114) (hvad der så ellers helt nøjagtigt sigtes til her?) ikke kunne være sagligt begrundet i Grundtvigs tankeverden som sådan, så kan jeg kun erklære mig enig. Det er jo netop det, jeg skriver helt omme på omslagets bagside, altså at der i bogen gøres udførligt rede for, »hvordan både indre, helt centrale, saglige og positive faktorer [fremh. her i GS], og ydre, til dels meget negative faktorer, bevirker, at Grundtvig fra 0.1835 mere og mere koncentrerer sig om det danske folkelivs bevarelse«. Hvor jeg vel at mærke taler om nogle helt anderledes indre og positive ting, end erkendelsen af »uigennemførligheden af dette vidskab-syn i modernitetens tidsalder «. For her mener jeg, at det er den ydre modstand og den manglende genklang, der har givet Grundtvig den hårde belæring om projektets uigennemførlighed. Så sent som i »Dansk Ravne-Galder« (skrevet 1860) er Grundtvigs drøm om både "Sorø« og »Göteborg" jo intakt.

Og hermed er vi nået frem til Theodor Jørgensens kritik af mig for at tale om "den virkelige Grundtvig" (i det følgende afsnit på side GS 114). Men det gør Grundtvig jo også selv. Nogle eksempler:

Allerede i »Imod den lille Anklager" (1815) taler Grundtvig om, hvordan han, hvis det ikke var for hans polemiske og apologetiske pligtarbejde, ville kunne vandre »i forbigangne Dage«, »sjunge med den Røst mig skiænkedes, udsige hvorledes jeg hørde Dage tale med Dage om deres Herre«. (LA 161 - GV 132f). I fortalen til »Nyaars-Morgen « udtrykker han $\mathrm{fx}$ håbet om at få »en lille Plet, hvor jeg kan prædike, hvad jeg troer, synge, hvad mig synes, og fortælle, hvad jeg seer, uden at drages med [...] det hele døde Vaesen, som er Tidens Pestilents [frem. her i GS] « (US IV 245-DP 90). Og i forbindelse med forsoningen med Chr. Molbech i 1826 skriver Grundtvig i et brev til denne, at når der kommer en afklaring på den kirkelige situation, vil han kunne få tid til at dyrke, hvad der er hans hjertes lyst og allerede længe har været hans »ivrige Syssel«, nemlig "poetisk og historisk, saa godt jeg kan, at opklare saavel det christelige som det danske Folke-Liv i de forrige Tider [...]« (M.-Gr. ${ }^{13} 141$ - DP 103). 
Jeg mener også, det er med rette, jeg gør den iagttagelse, at perioden fra efteråret $1806 \mathrm{og}$ op til foråret 1810 »er den eneste periode, hvor Grundtvig udfolder sig videnskabeligt på helt sin egen måde, og stort set rent positivt, uden at skulle indgå i større konflikter«, så at disse år har "sstor betydning med hensyn til forståelsen af, hvad der gennem hele resten af hans liv, og altså ofte gennem alle mulige konflikter og manøvrer, var hans egentlige anliggende(r)«(GV 49). Ligeledes mener, jeg, det er en rigtig iagttagelse, når jeg om »Krønike-Riim « (1829) siger, at »Sammen med bestræbelserne for at komme til England vidner disse rim om, hvad der var Grundtvigs egentlige lyst, så snart han kunne se sig fritaget for værnepligts- og kirkekampsbyrden« (GV 252).

Disse eksempler viser, at dén »egentlige« Grundtvig, jeg taler om, er en Grundtvig, der konkret (og vekselvirkende) beskæftiger sig med en historisk og poetisk tydning af tilværelsen og livet. Man kan altså ikke på én gang kritisere denne min tale om en »egentlig « Grundtvig, og så min tale om Grundtvigs "nedstigning" fra de universalhistoriske højder i 1832. For jeg siger jo netop ikke, at det er den Grundtvig, der er $s a ̊$ højt oppe, der er den »egentlige" Grundtvig!

Og så er der også det, at det jo var »Omkring Grundtvigs Vidskab«, der var titlen på min disputats, og ikke »Totaldigteren Grundtvig«, så at min »skuffelse" over Grundtvig i den forstand var en skuffelse, at min undersøgelses resultat var, at den store universalvidenskab, og i det hele taget den videnskabelige erkendelse i også Grundtvigs egen forstand, ikke spillede en så stor rolle for ham, som jeg - ud fra Kaj Thaning troede, da jeg startede projektet. Det har jeg klart gjort rede for i disputatsens indledning. Og jeg skal da også gerne indrømme, at jeg fra projektets undfangelse af havde en forventning om at finde nogle »erkendelsesgenveje« hos Grundtvig, som altså viste sig ikke at være der - $\mathrm{i}$ hvert fald ikke på den måde og i den grad, jeg havde forestillet mig. Jeg kan i denne henseende ganske tilslutte mig den konklusion, Theodor Jørgensen drager i det allersidste afsnit af sin opposition, hvor han jo netop også siger, at det er noget, min afhandling demonstrerer til fulde. Selv om han så føjer til, at »det måske ikke er det resultat hos læseren, som præses selv ville ønske«. Men i denne tilføjelse tager Theodor Jørgensen fejl, for det, jeg ønsker, er jo, at læseren skal kunne se resultatet af min undersøgelse. $O g$ det svarer i denne henseende nøje til, hvad Theodor Jørgensen siger, nemlig at 
Det er ikke som filosof eller erkendelsesteoretiker, at Grundtvig har haft eller vil kunne få betydning [...] Der er nogle fundamentalt vigtige ansatser ikke mindst i Danne-Virke-afhandlingerne, men de når ikke ud over det mere generelle. De omsættes og specificeres ikke i en udfoldet erkendelsesteori. Grundtvigs humanvidenskabelige betydning ligger i enkeltvidenskaberne, i filologien, mytologien, pædagogikken (GS 120).

Men min enighed med Theodor Jørgensen her kan ikke forhindre mig i, stadig at mene, at det nok var umagen værd - på en med tidens tarv og vilkår passende måde - at følge Grundtvigs ansatser op! Samtidig med, at vi også - netop inde i post-moderniteten lader os inspirere af »den egentlige Grundtvigs « mere konkret poetiske måde at tyde og forholde sig på.

At det er den indirekte gudserkendelse, der er den helt afgørende grund til, at det dennesidige livsengagement er kristeligt nødvendigt, det indebærer jo heller ikke, at der først og fremmest skal være tale om en erkendelse, der består i nogle resultater på universalvidenskabeligt topniveau - hvordan sådanne resultater så ellers vil se ud. Det er ganske vist dette indtryk, man får i Indledningen til »Nordens Mythologi«. Hvor selv den allerøverste videnskabeligheds udgangspunkt i og vekselvirkning med det konkret levede liv imidlertid også tillægges en helt afgørende betydning. I øvrigt kan topvidenskabeligheden som sagt også komme senere. Helt afgørende er under alle omstændigheder den gudserkendelse, der ligger i selve den kærlighedsfulde - og oplyste hengivelse til det konkrete, hvilket for Grundtvig vil sige folkelige, liv her og nu.

På det metodiske plan kritiserer Theodor Jørgensen mig for ikke at have arbejdet mere problemorienteret systematisk (GS 115). Og den kritik må jeg jo sådan set tage til mig. Idet jeg dog med glæde noterer, at Theodor Jørgensen (ligesom Anders Pontoppidan Thyssen - GS 96.109) anerkender, hvad jeg har ydet, for så vidt angår Dannevirkeafhandlingerne, og idet jeg spørger, hvad der egentlig ellers er at »systematisere - ud over, hvad jeg trods alt har gjort i disputatsens kapitel 9.

Men så kunne - og burde - jeg, siger Theodor Jørgensen, have arbejdet mere idehistorisk kontekstuelt, så jeg kunne have givet en uddybende besvarelse af spørgsmålet, hvilke overordnede problemstillinger i samtidens videnskabsteoretiske diskussioner, "Grundtvigs vidskab« 
forholdt sig til. Samtidig med en besvarelse af spørgsmålet, hvilken relevans den har i en nutidig videnskabsteoretisk diskussion (GS 115f).

Hvad det sidste angår, kan jeg jo henvise til mit forslag om, at vi på en eller anden måde nu forsøger at realisere Grundtvigs Göteborg-tanke! Og hvad i det hele taget den idehistoriske perspektivering angår, vil jeg sige, at jeg i forbindelse med mit projekt faktisk har læst en del almindelig erkendelsesteori og noget Kant, Fichte, Schelling, Herder og Locke m.fl. Samtidig med, at jeg jo også har studeret Scharlings Grundtvig-bog. Men måske har jeg manglet lysten og/eller evnen til at gå videre ad den vej. Eller også har jeg set nok til, selv at blive overbevist om, at det forholder sig, som jeg siger, at vel har Grundtvig været stærkt påvirket af sin tid, men at han på en enestående måde har taget alt, hvad der var værd at tage med af denne påvirkning, med ind i sit genuint kristne univers, hvor det er blevet indsmeltet i den fulde kristendom, der her er tale om. Man kan så bebrejde mig, at jeg ikke mere udførligt har gjort rede for dette forhold. Men det har jeg altså ikke. Bl.a. fordi jeg vidste, at andre og derpå klogere folk arbejdede med disse ting. $\mathrm{Og}$ endelig er der jo igen det forhold, at jeg på et tidspunkt bogstavelig talt så mig nødsaget til ændre mit arbejdes titel fra blot "Grundtvigs Vidskab« til »Omkring Grundtvigs Vidskab« - fordi det altså viste sig, at Grundtvigs forhold til den videnskabelige erkendelse (selv i hans egen jo særdeles vide forstand) måtte ses som del af en endnu større sammenhæng. Det anerkender Theodor Jørgensen også, når han siger, at min kritiske perspektivering af Grundtvig i hvert fald til dels legitimerer »den omstændelige gennemgang af hele Grundtvigs forfatterskab « (GS 114).

Jeg giver dog et eksempel eller to på, hvad det er jeg mener, når jeg siger, at jeg ikke har anset det for umagen værd i min sammenhæng at bruge tid og plads på en idehistorisk perspektivering.

I bogens Tillæg A »Forklaring/oplysning « nævner jeg, at jeg trods alt bl.a. har ledt efter den idéhistoriske baggrund (ud over den bibelske) for Grundtvigs brug af ordet og begrebet »forklaring ", men at »resultatet har været det nærmest chokerende, at en sådan baggrund ikke er fundet! Foruden diverse håndbøger har store dele af såvel Herders (se note 152 til her [GV] s. 188) som Schellings forfatterskab været afsøgt - men uden resultat. Det samme gælder en fremstilling som Paulus Svendsen: "Gullalderdrøm og utviklingstro«! « (GV 517).

Nu kan det selvfølgelig være, jeg ikke har ledt grundigt nok. Men det er under alle omstændigheder påfaldende, at det $\mathrm{i}$ hvert fald ikke har 
været ligetil at finde det. Og så er der den note, jeg henviser til i det netop citerede. Det er en note til det systematiske Dannevirke-afsnit $» \mathrm{Al}$ vidskab må være historisk «, og den vil jeg tillade mig at citere in extenso:

Se hertil GTE ${ }^{14}$ 130f, hvor Høirup bl.a. peger på »Impulser fra Herder «. Men også de Herder-elementer, der her måtte være tale om, er blevet underkastet den særlige Grundtvig'ske, »bibelske« omsmeltnings- og omstøbningsproces. Som led i nærværende undersøgelse har bl.a. »Auch eine Philosophie der Geschichte zur Bildung der Menschheit" og »Ideen zur Philosophie der Geschichte der Menschheit« været gennemsøgt med henblik på opsporing af "påvirknings-elementer«, ganske særligt med henblik på det helt centrale Grundtvig-begreb »forklaring " (se Tillæg A her s. 514ff). Men i det førstnævnte værk tales der kun om »Aufklärung « i almindelig pædagogisk-civilisatorisk betydning; der er intet fundet, som på nogen dybere måde kan ligge bag Grundtvigs tale om »forklaring «. - Og i den tale, der i »Ideen« kunne minde om Grundtvigs tale om forklarings-udviklingen, er det bogstavelig talt blot »Humanität «, det drejer sig om. Selv hvor Grundtvig måske har overtaget en ordlyd, er der i det egentlige indhold nærmest tale om det modsatte af, hvad det betyder hos Herder - også i det sted, som måske på sin vis kan være en del af baggrunden for det berømte »ingen-abekat « sted i I/NML ${ }^{15}$ : „Kein nachahmender Affe höherer Wesen sollte der zur Freiheit erschaffene Mensch sein, sondern, auch wo er geleitet wird, im glücklichen Wahn stehen, dass er selbst handle« (»Ideen« 195). - (GV 585f, note 152 til s. 188).

I forbindelse med sin efterlysning af en mere systematisk fremstilling spørger Theodor Jørgensen, hvad der fx virkelig skal forstås ved det, når jeg på side GV 115 taler om »Grundtvigs »særlige, dobbelt erfaringsbaserede erkendelsesteori«" (GS 116). Her burde jeg udtrykkeligt have henvist til netop min systematiske behandling af Dannevirke-artiklerne. For indirekte gør jeg det jo, når jeg til det pågældende sted i manuskriptet »Forelæsning over Roskilde-Riim « siger, at der »allerede her i 1814 «(GV 115) foreligger et udtryk herfor. Det, jeg sigter til, er jo, at for det første allerede selvbevidstheden ifølge Grundtvig er en erfaring, hvilket igen vil sige, at det er på erfaringens vej, mennesket kommer til "Sandhedens evige Grundsætning "(DV II 37. GV 177), og at det for det 
andet er "ved Anvendelse af Sandhedens Grundsætning paa Erfaringen at al fornuftig Sikkerhed og Vished ene er mulig « (DV II 37f. GV 190).

Theodor Jørgensen siger videre, at han gerne havde set en uddybning af, hvad jeg mener, når jeg (GV 132) om Grundtvigs opgør med Schelling i »Imod den lille Anklager « taler om de erkendelsesteoretiske perspektiver i Grundtvigs afvisning af såvel naturfilosofien som idealismen og kantianismen. Men det ligger jo i hele min fremstillings sammenhæng, at der her er tale om den erkendelsesteoretiske realisme, som også hænger sammen med afvisningen af den Schelling'ske monisme i godt/ondt- og sandhed/løgn-forholdet.

Endelig er der Theodor Jørgensens »overtagelse« af mit ellipsebillede til brug i forbindelse med en større udvikling af forholdet mellem det universelle og det partikulcere hos Grundtvig. Dertil vil jeg for det første sige, at det jo ikke var dette forhold, min undersøgelse gjaldt, og at jeg derfor heller ikke mener, det er særlig relevant i forbindelse med min tale om Grundtvigs "nedstigning" efter 1832. Selv om det jo er rigtigt nok, at nedstigningen fra universalvidenskabeligheden til den folkelige livsoplysning og til totaldigter-vekselvirkningen med folket også er en bevægelse fra det universelle til det partikulære. Og jeg kan da stort set også kun erklære mig enig med Theodor Jørgensen i hans betragtninger.

Men hvad mener Theodor Jørgensen, når han siger, at vejen til et universelt videnskabs-begreb går over folkeoplysningen, og at dennes sigte både er partikulært og universelt? (GS 118). Det universelle videnskabsbegreb fremgår vel af teologien om menneskeslægten og dens skabelsesbestemte liv og udvikling gennem historien. $\mathrm{Og}$ at der skal være en vekselvirkning mellem folkelivet og universalvidenskabeligheden, og mellem universalvidenskabeligheden og den folkelige livsoplysning, er en anden side af sagen. Derfor er det da også kun højst indirekte, den folkelige oplysnings sigte kan siges at være universelt. Selv om det jo er rigtigt, at Grundtvigs folkelige organismesyn kun er en del af hans organismesyn på hele menneskeslægten, så at Grundtvig altså selvfølgelig ikke kan tages til indtægt for en nationalistisk selvtilstrækkelighed. Det gælder også »super-universitetet» i Göteborg, som for det første skulle være et fællesnordisk projekt, og som for det andet udtrykkeligt skulle være det særligt nordiske bidrag til den samlede menneskeslægts universalhistoriske forklaringsvidenskabelighed og -udvikling. 
Hvad endelig kirkesynet angår, kan jeg kun være enig med Theodor Jørgensen, når han siger, at Grundtvigs koncentration om »den lille, egentlige kristne menigheds (gudstjenstlige) liv« [også kan] opfattes som en udvidelse af forståelseshorisonten til den kristne kirkes katolicitet « (GS 119). Det er jo noget, jeg - hvis jeg må have lov at nævne det - i allerhøjeste grad har levet efter i mit omfattende mellemkirkelige engagement $i$ både syd og øst op gennem 1990'erne. I hvilken forbindelse jeg jo også har erfaret, hvor godt det er at have den i økumenisk forstand universelle Grundtvig med sig ud i verden. Og dette gælder også, og ikke mindst, Sangværkets salmer. Jeg er glad for, at Theodor Jørgensen i denne sammenhæng udtrykkeligt nævner min behandling af det sidste afsnit i »Den christelige Børnelærdom《.

Men igen: det er ikke lige denne problematik, der står i centrum i min disputats. Og jeg kan heller ikke se, at de rigtige betragtninger, Theodor Jørgensen her fremsætter, kan spilles ud mod min måde at tale om Grundtvigs »nedstigning « på til fordel for en forståelse af Grundtvigs udvikling efter 1832 som »en voksende erkendelse af kristendommens vilkår i modernitetens tidsalder « (GS 120). Og da slet ikke, når det faktisk var i netop Indledningen til »Nordens Mythologi«, Grundtvig fremlagde den model for et kulturelt og videnskabeligt samliv og samarbejde mellem kristne og ikke-kristne, som også vil kunne bruges i vor post-moderne tid.

\section{Noter}

1. Et ganske lille og indirekte svar - nemlig på Ole Olesens anmeldelse af „Grundtvig-Studier« 1999 i Præsteforeningens Blad nr. 2000/13 - har jeg givet i samme blads nr. 2000/18 under overskriften »Der blev leveret vare! «.

2. Bent Christensen: »Fra drøm til program. Menneskelivets og dets verdens plads og betydning i N.F.S. Grundtvigs kristendomsforståelse fra Dagningen i 1824 over Opdagelsen i 1825 til Indledningen i 1832«. Licentiatafhandling fra 1985, udg. 1987.

3. FØNIX 1/1978.

4. $\mathrm{DP}=» \mathrm{Fra}$ drøm til program $\ll$.

5. L. Koch i »Fra Grundtvigianismens og den indre Missions Tid«, s. 19. Citeret Thaning: »Menneske først - « 501. GV 504.

6. „Den Danske Rigsdag" (nr. 38, 06.12.48 og nr. 39, 13.12.48).

7. Det gælder Kierkegaard-vinklen (og det kirkepolitiske aspekt) i denne tekst. P.G. Lindhardt: »Kierkegaard og Grundtvig« (Dansk Udsyn 1957 s. 147ff (og Præsteforeningens Blad 25.10.57), hvor der rettes en stærk kritik mod Grundtvig - og mod den kirkepolitiske strategi, der kommer til udtryk i Børnelærdommens 
sidste afsnit. Og Kaj Thanings svar: „Grundtvig og Kierkegaard» (Dansk Udsyn 1957 s. $348 \mathrm{ff})$.

8. Jeg bruger $\mathrm{i}$ denne sammenhæng ordet $\mathrm{i}$ en snævrere betydning end Aage Henriksen, som i en mere omfattende forstand taler om Grundtvigs nedstigning fra den højde, han nåede op i i 1824 (»Nyaars-Morgen«), »den lange nedstigning fra den fuldstændig ensomme position, som han havde arbejdet sig op i, nedstigningen, Grundtvigs forvandling til grundtvigianisme«. - Fl. Ettrup og Johs. H. Christensen (red.): »De levendes Land. Grundtvig 1984«, 1984, s. 61. Citeret DP 294.

9. Theodor Jørgensen indleder sin opposition med at gøre opmærksom på, at det er »resultatet af et præstegårdsliv med Grundtvig-studier, vi fejrer i dag«, og han leger med den tanke, at jeg måske vil skrive en tredje bog - som han har et forslag til titel til. Selv om den pågældende titel desværre delvis er identisk med titlen på min første Grundtvig-bog, idet forslaget nemlig ville være: »Mit liv med Grundtvig. Fra drøm til program «! (GS 111).

10. Ligesom det er mig en stor glæde, at der nu under Grundtvig-Akademiet er etableret et "Samtale-Forum omkring Grundtvigs universitets-tanker" (første møde 26.01.01), er det mig en glæde, at der sammesteds er blevet afholdt et nordisk seminar om »Grundtvigs poetik « (09-10.03.01)! Og min glæde over disse ting er så meget desto større, som initiativerne er taget uden nogen som helst medvirken fra min side! (For min e-mail om Göteborg-tanken til Akademiet i januar 2000 har vist ikke været nogen direkte med-årsag til det aktuelle SamtaleForum, som Uffe Jonas er initiativtager til). Men jeg deltager selvfølgelig begge steder.

11. »Fra 'Fra drøm til program' til program! Betragtninger og udkast fra en plads på Grundtvigs skuldre«, Dansk Kirketidende 7-8/1995. - »Livsvidenskabelig efterskrift«, Dansk Kirketidende 12-13/1998. - „Livspoetisk Indledning. Poesien på statholder-marken. En slags indfrielse af en bebudelse og i hvert fald et bidrag til samtalen om »at være grundtvigsk i dag««, Dansk Kirketidende 14-15/2000 og $16 / 2000$.

12. Hvad Theodor Jørgensen gør GS 112.

13. Chr.K.F. Molbech (udg.): „Christian Molbech og N.F.S. Grundtvig. En Brevvexling«. 1888.

14. Denne note kun her i GS: GTE = Henning Høirup: „Grundtvigs Syn paa Tro og Erkendelse. Modsigelsens Grundsætning som teologisk Aksiom hos Grundtvig«.

15. Denne note kun her $i$ GS: I/NML = Indledningen til »Nordens Mythologi«. 